\title{
Description and Relationships of Chaetopterus pugaporcinus, an Unusual Pelagic Polychaete (Annelida, Chaetopteridae)
}

\author{
KAREN J. OSBORN ${ }^{1, *}$, GREG W. ROUSE ${ }^{2} \uparrow$, SHANA K. GOFFREDI ${ }^{3}$, \\ AND BRUCE H. ROBISON ${ }^{1}$ \\ ${ }^{1}$ Monterey Bay Aquarium Research Institute, 7700 Sandholdt Rd., Moss Landing, California 95039; \\ ${ }^{2}$ South Australian Museum, Nth Terrace, Adelaide, SA 5000, Australia; and ${ }^{3}$ California Institute of \\ Technology, Dept. Environmental Science and Engineering, MC 138-78, 1200 East California Blvd., \\ Pasadena, California 91125
}

\begin{abstract}
An extraordinary new species, Chaetopterus pugaporcinus, is described from eight specimens collected from deep mesopelagic waters off Monterey Bay, California, by remotely operated vehicles. All specimens exhibit a consistent combination of both adult and larval characteristics, leaving in question the maturity of the specimens. All specimens lack ciliated larval bands and the stout, modified chaetae (cutting spines) typically found in segment A4 of chaetopterids. If the specimens described here are larvae, they are remarkable for their size, which ranged from 10 to $21 \mathrm{~mm}$ total length, nearly twice the length of the largest polychaete larvae previously reported and 5 to 10 times larger than known chaetopterid larvae. Then too, their lack of segment addition prior to settlement would be atypical. If adult, they are particularly unusual in their habitat choice and body form. Morphology of the uncini and comparison to larval morphology indicated a close relationship to either Chaetopterus or Mesochaetopterus. However, the lack of cutting spines and typical adult morphology made it impossible to determine to what genus this species should be allied. Thus, we carried out the first molecular phylogenetic analysis of the Chaetopteridae in order to appropriately place and name the new species. Three partial genes were sequenced for 21 annelid species. The sequencing also provides the first molecular evidence that Chaetopterus variopedatus sensu Hartman (1959) is not a single cosmo-
\end{abstract}

Received 14 November 2005; accepted 24 October 2006.

* To whom correspondence should be addressed. E-mail: oska@mbari.org

$\dagger$ Current address: Marine Biological Research Division, Scripps Institution of Oceanography, La Jolla, CA 92093-0202. politan species. The question of $C$. pugaporcinus being a delayed larva or a genuine holopelagic chaetopterid is discussed.

\section{Introduction}

Chaetopterids are an unusual polychaete group. All previously described species are benthic and tubiculous as adults. They have a body divided into three distinct regions - anterior, middle, and posterior-hereafter referred to as A, B, and C (after Crossland, 1904; Bhaud et al., 1994; Fig. 1c). Their larvae have a unique barrel-like form with one or two ciliated bands at the midsection and a large buccal funnel (Fig. 1a, b). Chaetopterid larvae are some of the largest among polychaetes, typically ranging in size from 0.4 to $2.5 \mathrm{~mm}$. The largest polychaete larvae reported, with a maximum length of $12 \mathrm{~mm}$, are the late stage of an unknown phyllodocid species (Tzetlin, 1998). Those phyllocdocid larvae consisted of a trochophore body and rudimentary adult trunk comprising up to 120 chaetigerous segments. Nozais et al. (1997) reported Poecilochaetus larvae with up to 50 segments and reaching nearly $10 \mathrm{~mm}$. Late-stage spionid and Magelona larvae have been reported to be nearly $5 \mathrm{~mm}$. Most polychaete larvae, however, seldom exceed $1.3 \mathrm{~mm}$ (Bhaud and Cazaux, 1987).

The taxonomy and systematics of the Chaetopteridae have never been comprehensively revised, and there is continuing confusion over the number of accepted species. For instance, Hartman (1959), following a suggestion by Fauvel (1927), synonymized all 25 Chaetopterus species into the single highly variable species $C$. variopedatus, 

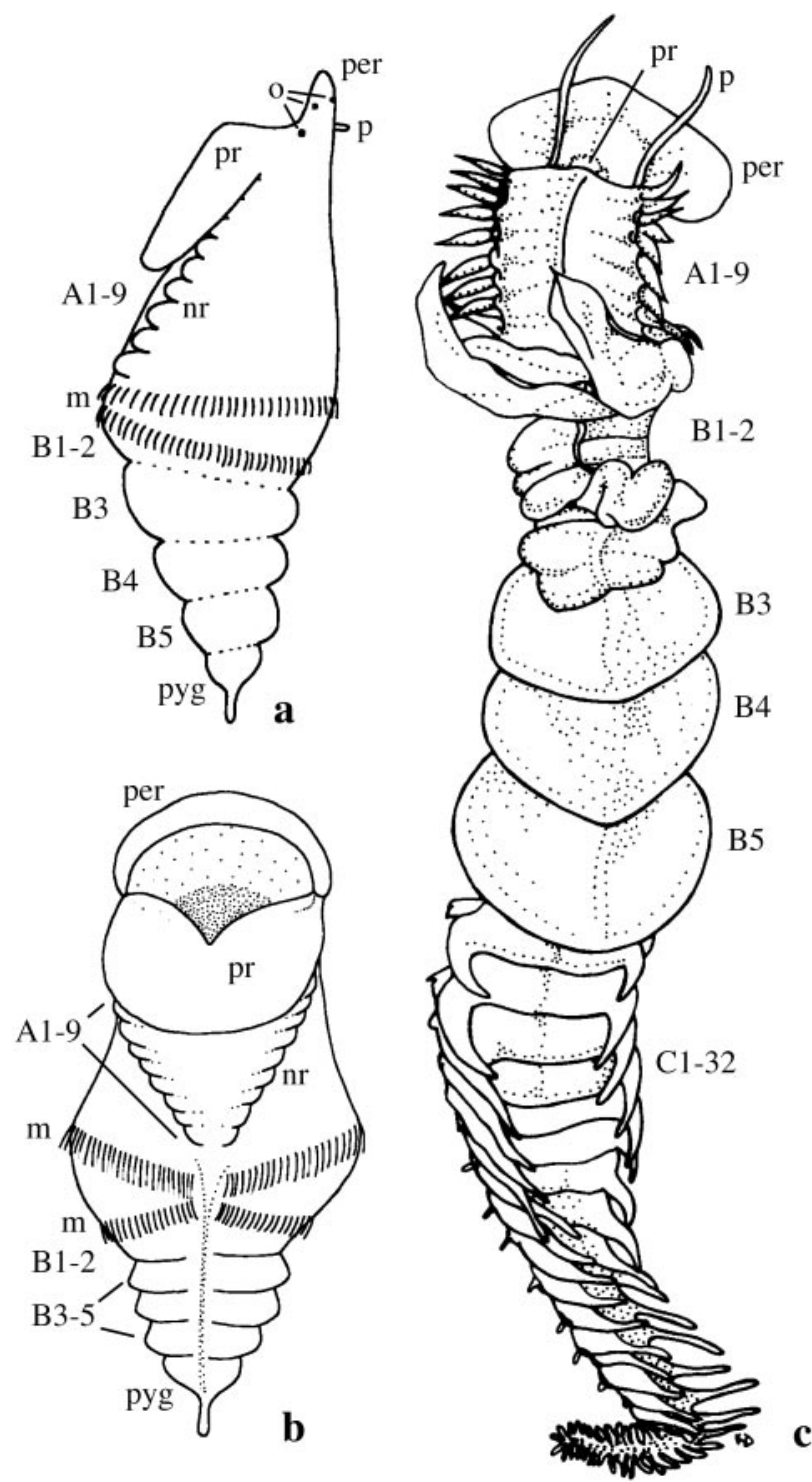

Figure 1. Chaetopterus L5 larvae (a) left lateral view and (b) dorsal view, redrawn from Irvine et al. (1999). (c) Chaetopterus adult, redrawn from Uschakov (1955). A, B, or C\# = region A, B, or C chaetigers, $\mathrm{m}=$ mesotroch, $\mathrm{nr}=$ notopodial rudiment, $\mathrm{o}=$ ocellus, $\mathrm{p}=$ palp, $\mathrm{per}=$ peristomium, $\mathrm{pr}=$ prostomium, $\mathrm{pyg}=$ pygidium .

suggesting that the species were local populations and reliable specific distinctions had not yet been found. In part this view of Chaetopterus may be due to the extended planktonic larval periods of some species whose larvae may remain in the water column for several months to over a year. Scheltema (1974) determined that the length of time chaetopterid larvae spend in the water column would easily allow their dispersal across ocean basins. This speculation supported the hypothesis of widespread genetic mixing and consequent taxonomic "lumping" to form large, cosmopolitan species complexes such as Chaetopterus variopedatus (Renier, 1804) and Spiochaetopterus costarum (Claparède,
1868). C. variopedatus is now considered a species complex that contains at least 18 species (Petersen, 1984a, b, 1997; Bhaud, 1998), though the redescriptions are yet to be formalized. Similarly, S. costarum has been shown to be a species complex (Bhaud and Fernandez-Alamo, 2000; Bhaud and Petti, 2001; Bhaud, 2003; Bhaud et al., 2003). Careful examination of Spiochaetopterus showed that, despite widespread larval dispersal, adult distributions of given species are far more limited than previously expected (Bhaud, 2003).

We describe here a new species, Chaetopterus pugaporcinus (Fig. 2), based on specimens that may be larvae or adults. We also present a phylogenetic analysis based on molecular data for the Chaetopteridae and provide the first molecular evidence to refute Hartman's proposal (Hartman, 1959) that Chaetopterus variopedatus is a single cosmopolitan species.

\section{Materials and Methods}

Eight specimens of the new species were observed and collected from the midwaters of Monterey Bay, California (Table 1), from 2001 to 2006. All in situ observations were made with the remotely operated vehicles Ventana or Tiburon (Robison, 1993). The ROV Ventana video system consisted of a Sony high-definition HDC-750A camera; the ROV Tiburon system was a Panasonic high-resolution, three-chip video camera. Video was recorded on high-quality BetaCam or HDTV tapes for subsequent analysis, and

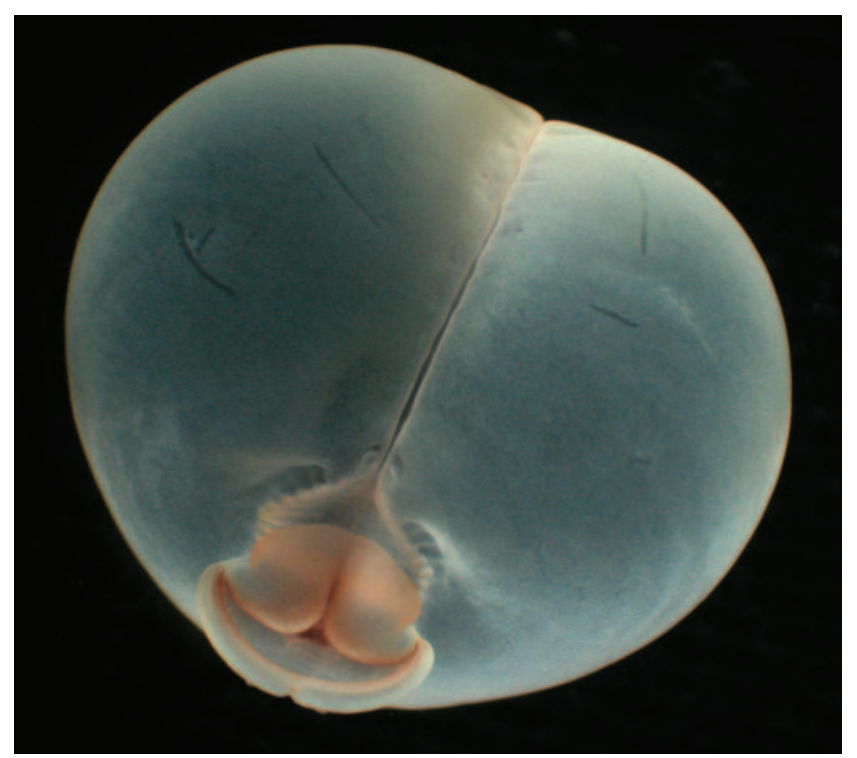

Figure 2. Chaetopterus pugaporcinus. Dorsal view of live animal, anterior end oriented down as always found in situ. The peristomium, prostomium, notopodia of chaetigers A3 through 9 and uncinal plate of A9 are visible, as is the middorsal ciliated groove. Palps are just discernible as two small lumps projecting below the peristomium. The anterior portion of chaetiger B2 is just visible at the top of the image. 


\begin{tabular}{|c|c|c|c|c|c|c|c|}
\hline Date & $\begin{array}{c}\text { Location near } \\
\text { Monterey Bay, CA }\end{array}$ & Accession no. & Fixative (fixative, preservative) & $\begin{array}{c}\text { Depth (m; } \\
\text { collection, } \\
\text { seafloor) }\end{array}$ & $\begin{array}{c}\text { Temp. } \\
\left({ }^{\circ} \mathrm{C}\right)\end{array}$ & $\begin{array}{c}\text { Salinity } \\
\text { (PSU) }\end{array}$ & $\begin{array}{c}\text { Oxygen } \\
(\mathrm{ml} / \mathrm{l})\end{array}$ \\
\hline 1 Oct. 2001 & $36.57^{\circ} \mathrm{N}, 122.52^{\circ} \mathrm{W}$ & SAM E3509 & Formalin & 1221,3500 & 3.4 & 34.5 & 0.56 \\
\hline 13 Dec. 2001 & $36.69^{\circ} \mathrm{N}, 122.05^{\circ} \mathrm{W}$ & $\mathrm{n} / \mathrm{a}$ & Frozen, ethanol & 990,1600 & 4.0 & 34.5 & 0.39 \\
\hline 3 Dec. 2002 & $36.69^{\circ} \mathrm{N}, 122.05^{\circ} \mathrm{W}$ & SAM E3508 & Formalin, ethanol \& sectioned & 1121,1600 & 3.6 & 34.5 & 0.52 \\
\hline 16 Dec. 2004 & $36.32^{\circ} \mathrm{N}, 122.89^{\circ} \mathrm{W}$ & Holotype LACM-AHF POLY 2173 & Formalin, ethanol & 1029,3500 & 3.8 & 34.4 & 0.41 \\
\hline 25 Mar. 2005 & $36.34^{\circ} \mathrm{N}, 122.29^{\circ} \mathrm{W}$ & Paratype LACM-AHF POLY 2174 & Gluteraldehyde, formalin & 965,3000 & 3.9 & 34.4 & 0.34 \\
\hline 9 Aug. 2005 & $36.71^{\circ} \mathrm{N}, 122.06^{\circ} \mathrm{W}$ & Paratype LACM-AHF POLY 2175 & Gluteraldehyde, formalin & 875,1600 & 4.3 & 34.5 & 0.24 \\
\hline 10 May, 2006 & $36.60^{\circ} \mathrm{N}, 122.38^{\circ} \mathrm{W}$ & $\mathrm{n} / \mathrm{a}$ & Formalin & 1098,1600 & 3.69 & 34.4 & 0.50 \\
\hline 24 Jun. 2006 & $36.65^{\circ} \mathrm{N}, 122.12^{\circ} \mathrm{W}$ & $\mathrm{n} / \mathrm{a}$ & Gluteraldehyde & 1203,2100 & 3.48 & 34.4 & 0.56 \\
\hline
\end{tabular}

these are housed in the video archive at the Monterey Bay Aquarium Research Institute. Specimens were captured in 7.5-1 detritus samplers, which preclude the crushing and abrasion typically inflicted on soft-bodied animals by nets (Robison, 1993). Specimens were transferred directly from the ROV to still-water aquaria at in situ temperatures, where they were observed and photographed. Live specimens were photographed with a Nikon Coolpix 5000 as macro shots in the aquaria, as well as through a Nikon BH-2 compound microscope. Line drawings were produced both from digital images and by using a camera lucida attached to the microscope.

Fecal pellets were collected from four specimens. Pellets were removed from the still-water aquaria in which the live specimens were held from time zero until 6 days after collection. Pellets were removed with a glass pipette and placed into $2 \%$ gluteraldehyde in filtered seawater with 0.1 mol $1^{-1}$ sodium cacodylate. Pellets were shredded with fine dissecting needles in the fixative to create a slurry, filtered onto $0.2-\mu \mathrm{m}$-pore polycarbonate filters (Osmonics, Inc.), air-dried, and coated with gold-palladium. Stubs were viewed on an ISI WB6 scanning electron microscope and digital images were captured.

\section{Taxa}

Two specimens (labeled 13 Dec. 2001 and 3 Dec. 2002 in Table 1) of the new species were destroyed for sequencing. Additional Chaetopterus were obtained from four locations (Table 2) to address the validity of the cosmopolitan species complex (Petersen, 1984a, b; Petersen and Britayev, 1997). Throughout this paper, we differentiate Chaetopterus specimens either as undescribed-when their morphology and locality do not match any previously published-or as sensu the original description name. Representatives of the remaining chaetopterid genera, Mesochaetopterus, Phyllochaetopterus, and Spiochaetopterus, were obtained to complete the ingroup sampling. There is no hypothesis for the sister group to the Chaetopteridae, thus nine taxa were selected as outgroup terminals (Table 2) spanning the large polychaete clade Canalipalpata that contains the Chaetopteridae. Terminals included examples from Sabellida, Cirratuliformia, Terebelliformia, and Spionida (sensu Rouse and Pleijel, 2001); unfortunately, specimens of Magelona and Apistobranchus, two candidate sister taxa, were unattainable for inclusion in this project. Specimens (Table 2) were collected intertidally, using scuba, or from deep water with the ROV Tiburon.

\section{Genetic data collection}

Worms used for genetic data collection were placed in $70 \%$ to $95 \%$ ethanol after collection. Voucher specimens were placed in the Los Angeles County Museum of Natural History (LACM) or the South Australian Museum (SAM) along with the types (see Table 2 for accession numbers). If a specimen was large enough (greater than $0.05 \mathrm{~g}$ ), tissue was cut from the midsection of the worm for DNA extraction, and the remains were preserved in formalin as the voucher. Genomic DNA was extracted from specimens by using DNAzol genomic DNA isolation reagent (Molecular Research Center, Inc., Cincinnati, OH) with the following modifications to the manufacturer's instructions. A 1- to 2- $\mathrm{mm}^{2}$ cube of tissue was homogenized in $500 \mu \mathrm{l}$ of DNAzol reagent and placed in a rotating incubator at room temperature for 24-72 h. For each 24-h period, $10 \mu \mathrm{l}$ of 10 $\mathrm{mg} / \mathrm{ml}$ proteinase kinase was added. To help visualize the DNA, $2 \mu \mathrm{l}$ of polyacryl carrier was added to each extraction. DNA was extracted from specimens of Paralvinella grasslei Desbruyères \& Laubier, 1982; Gunnarea capensis Johansson, 1927; Terebellides stroemii Sars, 1835; Spirorbis spirorbis (Linnaeus, 1758); Manayunkia athallasia Hutchings et al., 1981; Dodecaceria concharum Oersted, 1843; and Pectinaria granulata (Linnaeus, 1767) by using the Qiagen DNeasy tissue kit (Valencia, CA) according to the manufacturer's instructions.

An approximately 1800-bp fragment of small subunit ribosomal (18S) DNA was amplified with universal primers mitchA (5'-CAACCTGGTTGATCCTGCCAGT-3') and mitchB (5'- 
Table 2

Collection data and sequence information for outgroup and chaetopterid specimens

\begin{tabular}{|c|c|c|c|c|c|}
\hline Taxon & $\begin{array}{l}18 S \text { GenBank } \\
\text { Acc. \# }\end{array}$ & $\begin{array}{l}28 S \text { GenBank } \\
\text { Acc. \# }\end{array}$ & $\begin{array}{l}\text { COI GenBank } \\
\text { Acc. \# }\end{array}$ & $\begin{array}{l}\text { Museum Acc. } \\
\text { \# (voucher) }\end{array}$ & Collection Locality \\
\hline \multicolumn{6}{|l|}{ Outgroups } \\
\hline Dodecaceria concharum Oersted, 1843 Cirratulidae & AY577891 & DQ209242 & DQ209262 & SAM E3355 & Iceland \\
\hline $\begin{array}{l}\text { Paralvinella grasslei Desbruyères \& Laubier, } 1982 \\
\text { Alvinellidae }\end{array}$ & AY577886 & N/A & DQ209259 & SAM E3388 & Pacific \\
\hline Glyphanostomum sp. Ampharetidae & DQ209225 & DQ209240 & DQ209260 & SAM E3517 & Monterey Bay, CA \\
\hline $\begin{array}{l}\text { Pectinaria granulata (Linnaeus, 1767) } \\
\text { Terebelliformia }\end{array}$ & AY577890 & DQ209239 & DQ209258 & SAM E3358 & Iceland \\
\hline Terebellides stroemii Sars, 1835 Terebelliformia & AY577893 & DQ209241 & DQ209261 & SAM E3359 & Iceland \\
\hline Prionospio Spionidae & DQ209226 & DQ209246 & DQ209266 & SAM E3516 & Monterey Bay, CA \\
\hline $\begin{array}{l}\text { Manayunkia athallasia Hutchings et al., } 1981 \\
\text { Sabellidae }\end{array}$ & N/A & DQ209245 & DQ209265 & SAM E3518 & South Australia \\
\hline Spirorbis spirorbis (Linnaeus, 1758) Serpulidae & AY577887 & DQ209244 & DQ209264 & SAM E3357 & Iceland \\
\hline Gunnarea capensis Johansson, 1927 Sabellariidae & AY577892 & DQ209243 & DQ209263 & SAM E3360 & South Africa \\
\hline \multicolumn{6}{|l|}{ Ingroup Chaetopteridae } \\
\hline Spiochaetopterus bergensis (Gitay, 1969) & DQ209214 & DQ209229 & N/A & SAM E3558 & $\begin{array}{l}\text { Spitsbergen, } \\
\text { Norway }\end{array}$ \\
\hline Phyllochaetopterus sp. 3 & DQ209215 & DQ209230 & DQ209249 & SAM E3512 & Sydney, Australia \\
\hline Phyllochaetopterus sp. 1 & DQ209213 & DQ209228 & DQ209248 & SAM E3514 & Monterey Bay, CA \\
\hline Phyllochaetopterus sp. 2 & DQ209216 & DQ209231 & DQ209250 & SAM E3513 & Sydney, Australia \\
\hline Phyllochaetopterus socialis Claparède, 1868 & DQ209212 & DQ209227 & DQ209247 & N/A & Roscoff, France \\
\hline Mesochaetopterus taylori Monro, 1928 & DQ209217 & DQ209232 & DQ209251 & SAM E3570 & Friday Harbor, WA \\
\hline Mesochaetopterus japonicus Fujiwara, 1934 & DQ209218 & N/A & N/A & SAM E3571 & Kyushu, Japan \\
\hline Chaetopterus sarsii Boeck, 1861 & DQ209221 & DQ209235 & DQ209254 & SAM E3557 & $\begin{array}{l}\text { Trondheimsfjord, } \\
\text { Norway }\end{array}$ \\
\hline Chaetopterus sp. 1 & DQ209219 & DQ209233 & DQ209252 & SAM E3511 & Santa Barbara, CA \\
\hline Chaetopterus sp. 2 & DQ209222 & DQ209236 & DQ209255 & N/A & Banyuls, France \\
\hline Chaetopterus cf. luteus Stimpson, 1856 & DQ209220 & DQ209234 & DQ209253 & SAM E3510 & South Australia \\
\hline C. pugaporcinus (2 specimens) & $\begin{array}{l}\text { DQ209224, } \\
\text { DQ209223 }\end{array}$ & $\begin{array}{l}\text { DQ209238, } \\
\text { DQ209237 }\end{array}$ & $\begin{array}{l}\text { DQ209257, } \\
\text { DQ209256 }\end{array}$ & $\begin{array}{l}\text { LACM POLY } \\
2173-2175\end{array}$ & Monterey Bay, CA \\
\hline
\end{tabular}

TGATCCTTCCGCAGGTTCACCTAC-3') modified from Medlin et al. (1988). The amplification profile was optimized for each extraction: 35 ramping cycles of $94{ }^{\circ} \mathrm{C}$ for $60 \mathrm{~s}$, $58-64{ }^{\circ} \mathrm{C}$ for $60 \mathrm{~s}, 72{ }^{\circ} \mathrm{C}$ for $90-120 \mathrm{~s}$, with an initial single denaturation step at $94{ }^{\circ} \mathrm{C}$ for 3 min and a final single extension step at $72{ }^{\circ} \mathrm{C}$ for $4-7 \mathrm{~min}$. An approximately 650-bp fragment of the mitochondrial $C O I$ gene was amplified using primers HCO2198 (5'-TAAACTTCAGGGTGACCAAAAAATCA-3') and LCO1490 (5' -TCAACAAATCATAAAGATATTGG-3') (Folmer et al., 1994). The amplification profile was optimized for each extraction, optionally with a touchdown of five cycles of $94{ }^{\circ} \mathrm{C}$ for $60 \mathrm{~s}, 45^{\circ} \mathrm{C}$ for $90 \mathrm{~s}, 72^{\circ} \mathrm{C}$ for $60 \mathrm{~s}$, and then 35 cycles of $94{ }^{\circ} \mathrm{C}$ for $30-40 \mathrm{~s}, 51^{\circ} \mathrm{C}$ for $30-90 \mathrm{~s}, 72{ }^{\circ} \mathrm{C}$ for $60 \mathrm{~s}$, with an initial single denaturation step at $94{ }^{\circ} \mathrm{C}$ for $60-120 \mathrm{~s}$ and a final single extension step at $72{ }^{\circ} \mathrm{C}$ for $5-7 \mathrm{~min}$. An approximately 1100 -bp fragment of large subunit ribosomal (28S) DNA was amplified with modified universal primers (Lenaers et al., 1989) LSUD1F (5'-ACCCGCTGAATTTAAGCATA-3') and D3ar (5'-ACGAACGATTTGCACGTCAG-3'). The amplification profile was optimized for each extraction: 35 cycles of $94{ }^{\circ} \mathrm{C}$ for $40-60 \mathrm{~s}, 60{ }^{\circ} \mathrm{C}$ for $30-60 \mathrm{~s}, 72^{\circ} \mathrm{C}$ for $70-120 \mathrm{~s}$, with an initial single denaturation step at 94 ${ }^{\circ} \mathrm{C}$ for $5 \mathrm{~min}$ and a final single extension step at $72{ }^{\circ} \mathrm{C}$ for 5-7 min.

PCR products were either sequenced directly after spin column purification (Ultrafree-DA columns, Millipore, Billerica, MA), following the manufacturer's protocol or, in a few cases, cloned according to the manufacturer's protocol of the Invitrogen (Carlsbad, CA) TOPO cloning kit. In the latter case, three to six colonies were chosen for plasmid DNA purification using a QIAprep spin miniprep kit (Qiagen, Valencia, CA). Plasmid DNA was digested with EcoRI to check for correct-size inserts. Cloned DNA was sequenced in both directions using M13 primers. All direct sequencing was carried out using the same primers that were used in the amplification, with the addition of three internal primers for $18 S$ (514F 5' -TCTGGTGCCAGCAGCCGCGG-3'; 1055F 5'-GGTGGTGCATGGCCG-3'; 1055R 5'-CGGCCATGCACCACC-3'). All sequencing was carried out with the BigDye terminator ver. 3.1 sequencing kit and analyzed on an ABI 3100 capillary sequencer (Applied Biosystems, Foster City, CA). Sequences were deposited in GenBank (accession numbers are listed in Table 2). 


\section{Analysis}

At least two of the three gene sequences were obtained from most samples (Table 2), with the exception of one ingroup taxon, Mesochaetopterus japonicus. The topology of the trees did not change whether or not taxa with missing sequences were included. We used a criterion that sequences could only be concatenated for a combined analysis when sequenced from the same individual. None of the previous chaetopterid sequences available from GenBank met this criterion; thus no sequences from GenBank were used in the final analyses.

Sequences were aligned with T-coffee (Notredame et al., 2000) and proofread by eye in MacClade ver. 4.04 OS X (Maddison and Maddison, 2000). Four separate preliminary Bayesian analyses were run on the aligned sequences with differing amounts of the alignments excluded. The most conservative analysis excluded any base for which any sequence contained a gap; the most inclusive included all regions. Two other analyses contained intermediate amounts of ambiguously aligned bases: one more conservative, in which any base for which 8 or more taxa had a gap was removed; the other less conservative, in which any base for which 16 or more taxa had a gap was removed. All were run as described below for the final Bayesian analyses but with only 11 million generations. No differences in ingroup generic relationships or in the relative support for the clades of interest were found among the four analyses; thus arbitrary removal of data was avoided by retention of all bases in subsequent analyses (see supplementary material at http://www.biolbull.org/supplemental/). No ambiguously aligned bases were removed from the final analyses $(18 S=$ $12.3 \%$ ambiguously aligned; $28 S=14.3 \%$ ambiguously aligned; $C O I=0 \%$ ambiguously aligned). The alignments are deposited in GenBank and TreeBase, and are available from KJO.

Parsimony analyses were conducted with the PAUP $4.0 \mathrm{~b} 10$ software package (Swofford, 2002). Parsimony trees were reconstructed from an equally weighted character matrix and the heuristic search option, using the tree-bisectionreconnection branch-swapping algorithm and 1000 random addition replicates. Gaps were treated as missing data because of the four taxa with missing sequences. Bootstrap and jackknife (37\% deletion) values were obtained with the same settings as the parsimony analysis.

Bayesian analyses of the data sets were conducted using MrBayes 3.0b4 (Huelsenbeck and Ronquist, 2001). Standard procedures based on Modeltest 3.5 (Posada and Crandall, 1998) were implemented in PAUP to select the most appropriate models for the analyses. The relative fit of models was assessed by the Akaike information criterion, AIC $=-2 \ln L+2 n$ where $L$ is the maximum likelihood score and $n$ is the number of free parameters of the model. Smaller values of AIC are preferred (Akaike, 1974; Posada and Crandall, 2001), and the General Time Reversible + Proportion Invariant + Gamma $(\mathrm{GTR}+\mathrm{I}+\Gamma)$ represents the optimal model with respect to the $18 \mathrm{~S}$ and $28 \mathrm{~S}$ data and General Time Reversible + Site Specific (GTR + SS) with respect to the COI data. Genes were unlinked in the concatenated analyses. Each markov chain, three heated and one cold, was started from a random tree and all four chains ran simultaneously for 3 to 52 million generations (see below), with trees being sampled so that the resulting data set from each run contained at least 10,000 data points after at least 1000 had been discarded as burnin. Tracer ver. 1.2 (Rambaut and Drummond, 2003) was used to check autocorrelation of individual parameters and to check that the 1000 generations discarded as burnin were sufficient to ensure that the chain had reached convergence before inference from the Markov chain Monte Carlo data set was made. Several repetitions of the analysis converged on similar parameter estimates (numerous runs of $c a .3$ million, three runs of 11 million, one run of 31 million for individual genes and 52 million for the concatenated sequences).

\section{Results}

\section{Systematics}

CHAETOPTERIDAE Audouin \& Milne-Edwards, 1833 Chaetopterus Cuvier, 1830

Chaetopterus pugaporcinus, new species

\section{Type material}

The holotype, collected from Monterey Bay, California, $36.32^{\circ} \mathrm{N}, 122.89^{\circ} \mathrm{W}$, in December 2004 by KJO and BHR, is deposited at the Los Angeles County Museum of Natural History Allan Hancock Foundation Polychaete Collection (LACM-AHF POLY 2173). All specimens collected are of undetermined sex. Four paratypes exist and are deposited, two at LACM (LACM-AHF POLY 2174 and 2175) and two at the South Australian Museum, Adelaide (SAM E3508, E3509). One specimen is partially sectioned along the longitudinal axis of the body; the region-A chaetae are mounted on permanent slides; the remaining tissue, consisting of anteroventral body, is in 70\% ethanol (SAM E3508). Tissue from an additional specimen, originally frozen and now in chilled 95\% ethanol, and that of two additional specimens is retained by $\mathrm{KJO}$ at the Monterey Bay Aquarium Research Institute.

\section{Diagnosis}

Small to medium-sized (10-21 mm in body length and width) Chaetopterus with peristomium and prostomium resembling larval preoral and postoral lobes (Fig. 1 and Fig. 3b). Peristomial palps short, rudimentary to as long as peristomium. Eyes absent. A middorsal ciliated groove running from posterior margin of segment A9 to at least pos- 

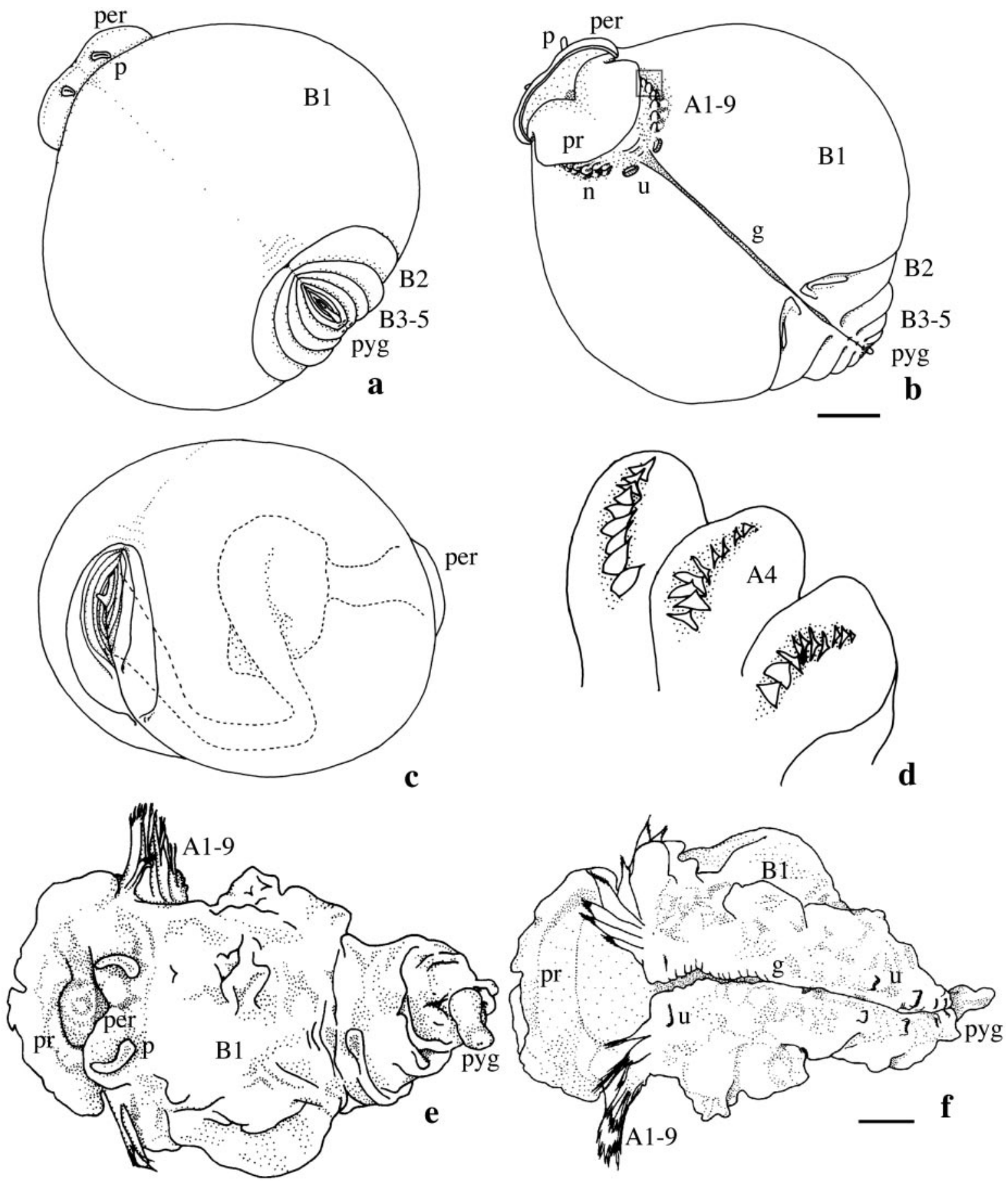

Figure 3. Chaetopterus pugaporcinus. (a) Ventral view. (b) Dorsal view (box indicates area of enlargement in (d). (c) Right posterolateral view showing sigmoid path of gut through expanded chaetiger B1. (d) Enlargement of notopodia of chaetigers A3-5. Tips of lanceolate chaetae are just visible projecting from slight elongate groove from dorsal surface to distal tip. (e) Ventral and (f) dorsal views of preserved holotype. A \& B\# $=$ region $\mathrm{A}$ and $\mathrm{B}$ chaetigers, $\mathrm{g}=$ middorsal ciliated groove, $\mathrm{n}=$ notopodia, $\mathrm{p}=$ palp, per $=$ peristomium, $\mathrm{pr}=$ prostomium, pyg $=$ cylindrical pygidium, $\mathrm{u}=$ uncinal plate. Scale bars: (b) $4 \mathrm{~mm}$, (f) $1 \mathrm{~mm}$.

terior margin of region $\mathrm{B}$. Body with two or three regions (regions $\mathrm{A}, \mathrm{B}$, and $\mathrm{C}$, with segments of each region numbered separately as A1, A2, etc.; B1, B2, etc.). Region A with 9 chaetigers, parapodia uniramous except A9, with neuropodia as uncinal plates, notopodial lobes short and simple, lanceolate chaetae just projecting from dorsal to distal surface, lacking cutting spines. Region B composed of two greatly expanded, biramous segments (B1 and B2) and 
three additional uniramous segments, B1 much larger than B2, notopodia of B1-2 with up to 10 internal chaetae, neuropodia as uncinal plates in a single lobe. Region $\mathrm{C}$ consists of one segment at most and the pygidium, possibly with uncinal plates. Compressed nature of region $\mathrm{C}$ leaves room for further interpretation of segmentation there. Body formula $=9 \mathrm{~A}, 5 \mathrm{~B}, 1(+1) \mathrm{C}=15$ segments.

\section{Type locality}

Monterey Bay, California, $36.32^{\circ} \mathrm{N}, 122.89^{\circ} \mathrm{W}$, from $1029 \mathrm{~m}$ where the seafloor is $3500 \mathrm{~m}$ deep.

\section{Etymology}

The species is named pugaporcinus (based on the following Latin roots and suffix respectively: puga = rump; porcus = pig; and inus = having the likeness of) for its resemblance to the "rump of a pig." Puga and porcus are nouns in opposition, resulting in a masculine specific epithet to agree in gender with Chaetopterus. For the sake of simplicity and euphony, an "a" was chosen as the connecting vowel instead of the usual "ato" or "i."

\section{External}

Holotype $17 \mathrm{~mm}$ long in life, paratypes $10-21 \mathrm{~mm}$ long in life. Region A with 9 segments, compressed so notopodia project anteriorly under prostomium, forming an arch running dorsoventrally (Figs. $3 \mathrm{~b}$ and $4 \mathrm{c}$ ). Each A-region notopodium with 6-10 lanceolate chaetae (Fig. 3d). Segment A9 with neuropodial uncini on either side of anteriormost portion of middorsal ciliated groove (Fig. 3b). Middorsal ciliated groove beginning at posterior margin of segment A9, continuing to at least posterior margin of region B. Prostomium large (to $20 \%$ of body length), bilobed, and folding towards the posterior (Figs. $3 b$ and 4a). Peristomium broadly horseshoe-shaped, with short (no longer than length of peristomium) grooved palps; no eyes. Region B wth 5 segments. Segment B1 greatly enlarged, accounting for more than $80 \%$ of body length, and as broad as animal is long. Segment B2 nearly one-fourth as long as B1 at longest, B3-B5 compressed. Inflation of B1 and compression of anterior and posterior segments gives animal a nearly spherical appearance when undisturbed (Fig. 2). When disturbed, animal contracts, withdrawing region A, segments B3-5, region $\mathrm{C}$, and the middorsal ciliated groove toward the body center (Fig. 4b). Neuropodial uncinal plates on posterior margin of segments in regions $\mathrm{B}$ and $\mathrm{C}$, lateral to middorsal ciliated groove and with a single row of uncini. The sectioned specimen revealed notopodia in segments B1 and B2 with up to 10 internal, simple chaetae lateral to the uncinal plates. Region $\mathrm{C}$ difficult to discern from pygidium but seems to consists of 1 uniramous segment. The pygidium consists of a cylindrical appendage immediately dorsal to the anus.
Live animal semitransparent white to beige with dark brown to purple pigment lining interior of buccal region. Gut packed with dark material, making it easily distinguishable through body wall (Figs. 3c and 4b, d). No glandular plate, ventral shield, or plastron is found. Cilia present only in the middorsal, ciliated groove and lining interior of buccal region.

\section{Chaetae}

No stout, modified chaetae (cutting spines) on segment A4. Lanceolate chaetae in notopodia A1-A9 (Fig. 4e), measuring 1.14 to $2.34 \mathrm{~mm}$ long and up to $0.07 \mathrm{~mm}$ wide from an 18-mm-long specimen (SAM E3508), with longest chaetae found in chaetiger A5.

Uncini (Fig. 4f, g) present posteriorly in all chaetigers from A9. Ten to more than 40 uncini per uncinal plate, A9 consistently contained the most, with decreasing numbers found in posterior chaetigers. General uncinal shape is ellipsoid or rounded-rectangular, measuring 37 by $22 \mu \mathrm{m}$ in maximum dimensions; decreasing slightly in posteriormost segments. Teeth are prominent and few, 8-12. Tooth roots are slightly oblique relative to anterior-posterior direction of uncinal plate. Posterodorsal face with distinct shoulder overhanging a concavity leading to a sharp heel projecting slightly from flat or convex sole. Ventral insertion zone roughly convex, with posterior height less than the anterior height. Uncini of region B as above (Fig. 4g) to those with less pronounced shoulder and concavity above the projecting heel (Fig. 4f).

\section{Internal}

Dorsoventrally broadened S-shaped gut projects into cavity formed by segments B1 and B2, arching ventrally and then dorsally before decreasing abruptly and traveling along dorsal body wall directly to anus (Fig. 3c). Small orange, glandular organ attached to posterior portion of digestive tract within B3-5 segments, and numerous pouches of connective tissue attached to the gut and filled with fluid. Interior of B1 and B2 forming a well-developed coelomic cavity filled with the fluid-filled pouches. Septa are distinct between region A segments but incomplete between region B and $\mathrm{C}$ segments, which are indicated by the presence of uncinal plates and annulations on the external surface (Fig. 4b-d).

One half of one paratype (SAM E3508) was sectioned longitudinally to search for gametogenic tissue and to examine septation and internal chaetae. No decisive gametogenic tissue was found. No gametes were seen through the nearly transparent body walls of any of the individuals collected.

\section{Remarks}

The unusual body form of $C$. pugaporcinus allows few direct morphological comparisons with described chaetop- 

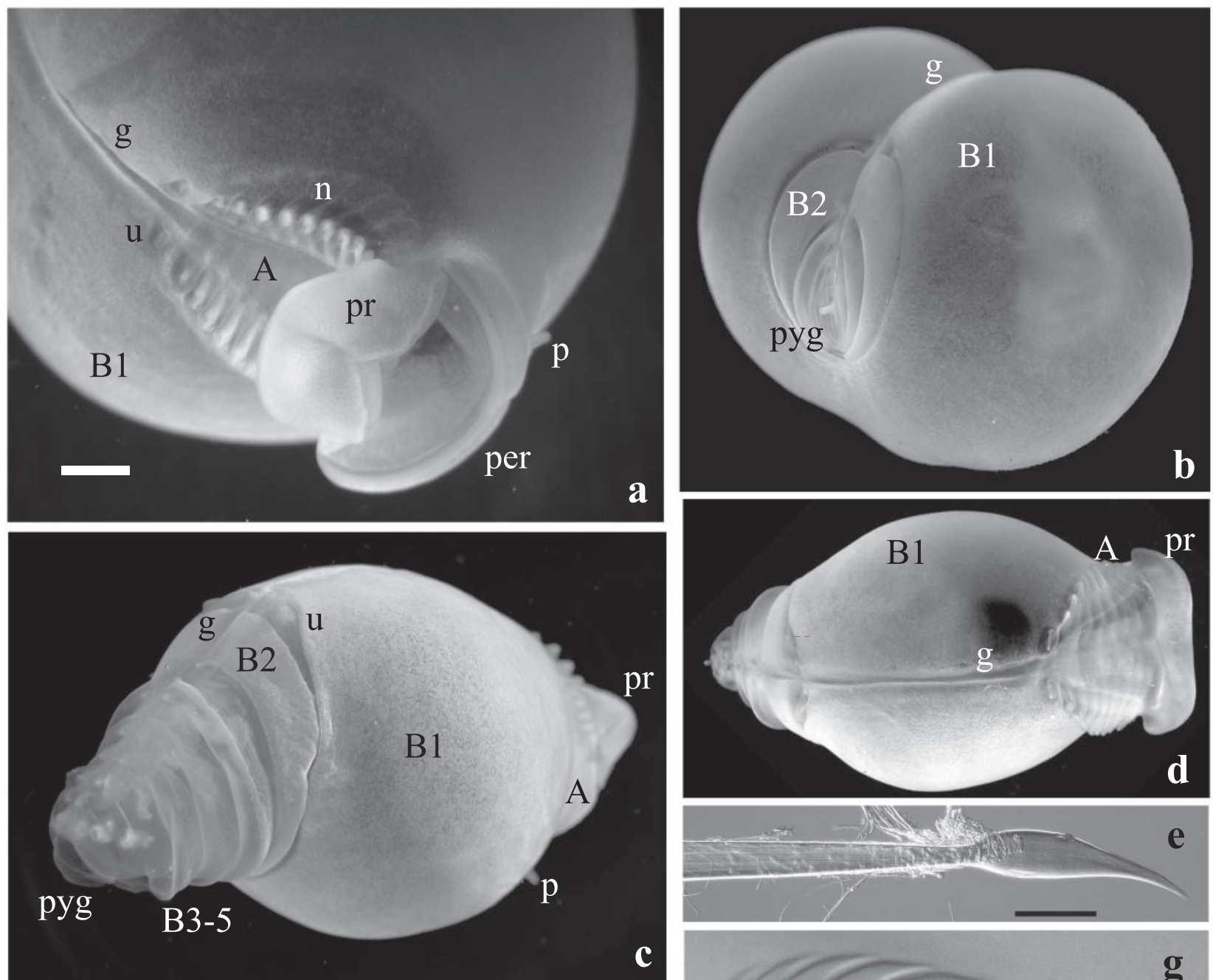

C
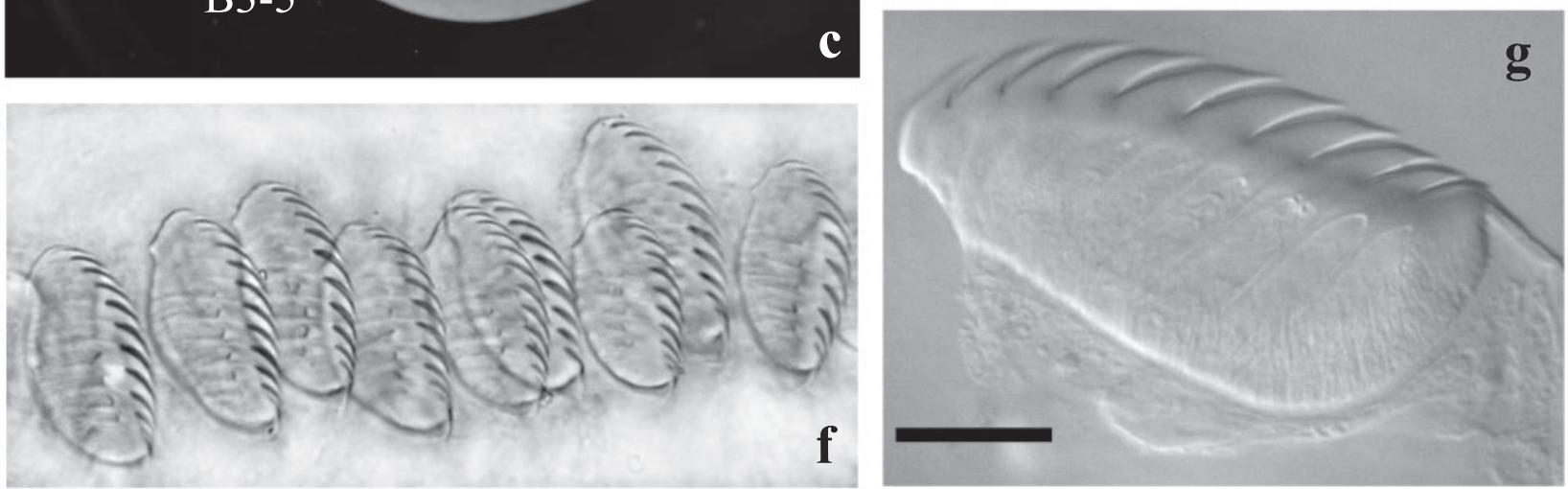

Figure 4. Chaetopterus pugaporcinus. (a) Left anterodorsal view. (b) Right posterolateral view of animal with midventral ciliated groove contracted and seen at the top. (c) Right posterolateral view of relaxed animal such that chaetigers B3-5 and the pygidium are extended. (d) Dorsal view of relaxed animal with all chaetigers extended. (e) Lanceolate chaeta of segment A5. (f) Nine unicini from center of the single row from B2. (g) Uncinus from A9 with muscular support lost during dissection. The support attached to the sharp heel below teeth 3 and 4 . A \& B\# = region A and B chaetigers, $g=$ middorsal ciliated groove, $\mathrm{n}=$ notopodia, $\mathrm{p}=$ palp, per $=$ peristomium, $\mathrm{pr}=$ prostomium, $\mathrm{pyg}=$ cylindrical pygidium, $\mathrm{u}=$ uncinal plate. Scale bars: (a) $3 \mathrm{~mm},(\mathrm{e}, \mathrm{g}) 10 \mu \mathrm{m}$.

terids. This novel species is morphologically most similar to Chaetopterus and Mesochaetopterus on the basis of larval form, size, and uncinal form. Angle of the tooth roots, relative to the anterior-posterior direction of the uncinal plate, has been used (Bhaud, 2003) to distinguish Mesochaetopterus (perpendicular) from Chaetopterus (oblique). 
Chaetopterus pugaporcinus uncini are most similar to those of Chaetopterus, yet the morphology suggests that this feature may vary more than shown by Bhaud's (2003) examples. The new species also resembles Chaetopterus in having five region-B segments, although their form differs considerably from those previously described in Chaetopterus larvae or adults. The short palps are typical of Chaetopterus. These three features alone are insufficient to determine the taxonomic affinities of this unusual species.

This new species differs from all previously described Chaetopterus species in the general form of the body (spherical body consisting of segment $\mathrm{B} 1$ and $\mathrm{B} 2$, with remaining segments compressed to the anterior and posterior surfaces of the two enlarged segments); the shape of the uncini (overhang, concavity, and sharp heel on the posterior-dorsal face); the lack of cutting spines on segment A4; and the presence of internal notochaetae in B2. The molecular data further support the uniqueness of this species (total uncorrected divergence $=$ 18S: $0.4 \%-1.6 \%$, 28S: $1.7 \%-7 \%$, COI: $18 \%-21 \%$ ) when compared to other Chaetopterus. The novelty of this species extends beyond the differences mentioned above, to the combination of larval and adult features and extended use of the larval habitat. It is not yet possible to determine whether the specimens are the first pelagic member of Chaetopteridae to be described or gigantic larvae that have yet to metamorphose and settle, because no reproductive individuals have been found.

Chaetopterus pugaporcinus resembles L5 stage (competent to metamorphose) Chaetopterus larvae (Irvine et al., 1999 ) in many ways. Typical chaetopterid larvae are compact, barrel-shaped, and nearly as wide as long in earlier stages; they elongate as they age. They possess one or two ciliated mesotrochal rings (Blake, 1996, reports as many as three) and adult chaetae (Bhaud, 2003). The form of the prostomium and peristomium of $C$. pugaporcinus resembles enlarged larval preoral and postoral lobes, with the prostomium folding dorsally. The arrangement of region A segments after relaxation, the form of pygidial tissue ventral to the anus, the lack of dorsal-ventral flattening of region A, the lack of elongation of the entire body, and the pelagic habitat are additional similarities shared with larval chaetopterids. L6 stage Chaetopterus larvae (mid-metamorphosis) differ from $C$. pugaporcinus in the form of the prostomium and peristomium, the general shape of region A, the presence of aliform notopodia in segment B1, the development of an accessory feeding organ, and the relative size and shape of segments in region B and C (Irvine et al., 1999). Thus, the specimens described here have not yet developed the morphology of L6 stage larvae as described by Irvine et al. (1999).

Despite the similarities to L5 stage Chaetopterus larvae, there are also several notable differences. Chaetopterus pugaporcinus lacks ciliated trochal bands, a key larval characteristic. The trochal bands are present into L6 stage larvae, when they are incorporated into the aliform notopodia of segment B1 (Irvine et al., 1999). None of the elaborate notopodia often found in other chaetopterids have been observed in C. pugaporcinus. L5 stage Chaetopterus show no external evidence of segmentation surrounding the mesotrochs (the tissue that will become segments B1-2, Irvine et al., 1999), whereas C. pugaporcinus has well-developed B1 and B2 annulations and biramous parapodia on these segments. Also, just anterior to the pygidium, L5 larvae possess a pair of lateral outgrowths that will become notopodia of segment C1 (Irvine et al., 1999); C. pugaporcinus lacks these notopodia. Several nonlarval features are present in C. pugaporcinus, including well-developed septation of segments A1-9, infolding of the epidermis designating segments of regions $\mathrm{B}$ and $\mathrm{C}$, uniramous parapodia in segments following B2, and an enlarged coelomic cavity within region $\mathrm{B}$.

Mesochaetopterus larvae are the largest chaetopterid larvae reported to date, reaching as much as $2.5 \mathrm{~mm}$ in length, whereas most chaetopterid larvae range from 0.4 to $1 \mathrm{~mm}$ (Bhaud and Cazaux, 1987). The specimens described here were nearly an order of magnitude larger than any chaetopterid larvae reported previously. Despite the 11-mm range in total length observed, specimen morphology was consistent from one specimen to the next, differing only in the length of the peristomial palps and possibly the number of segments in region $\mathrm{C}(+1)$. Palp length appears correlated to the specimen size: rudimentary palps were found on the smallest specimens and longer palps on larger specimens. As is characteristic of Chaetopterus, even the longest palps were never longer than the peristomium. The specimen that may have an additional region $\mathrm{C}$ segment was not the largest specimen collected. Specimens shrank considerably when damaged and shriveled further when preserved, even when relaxed prior to preservation. Preserved specimens measure $4-11 \mathrm{~mm}$. Shrinkage is commonly observed in pelagic polychaetes, especially tomopterids, alciopids, and typhloscolecids (KJO, pers. obs.). Sizes of larvae reported in the literature are likely a mixture of live and preserved measurements, with the largest measurements taken from fresh material. Thus our measurements (up to $21 \mathrm{~mm}$ ) can be directly compared to Bhaud and Cazaux's (1987) greatest measurement of $2.5 \mathrm{~mm}$.

\section{Ecology}

Chaetopterus pugaporcinus has been found in the water column between 875 and $1221 \mathrm{~m}$, in water 1600 to $3500 \mathrm{~m}$ deep. The animal is neutrally buoyant when uninjured and remained so in the laboratory for as long as 6 days. If an animal was injured, region B shriveled and the specimen sank to the bottom of the aquarium.

In situ specimens were observed attached to a cloud of mucus that was several times the size of the animal. Water disturbance generated by the ROVs caused separation of the 
animals from their mucous clouds. Specimens held in the laboratory were observed to produce mucus that formed unorganized clouds from the middorsal ciliated groove and from the cylindrical pygidial projection dorsal to the anus. The resulting mucous cloud was not released by the animal but remained in contact with the cylindrical pygidial projection (Figs. 3c and 4b). Fecal pellets were found in the mucous cloud after several hours.

It is assumed that feeding occurs by collection of sinking marine "snow" particles in the mucus produced from the middorsal ciliated groove. Periodically, the mucous cloud would have to be drawn into the mouth and the aggregate consumed. Feeding by collection of particles on mucus is common in pelagic larvae and other gelatinous zooplankton. For example, Poecilochaetus larvae are reported to produce a three-dimensional network of mucous strands that they then move along individually while feeding on small particles that adhere to the strands (Hamner et al., 1975), and larval pectinariids were recently shown to utilize a mucous filter while feeding in the water column (Pernet, 2004). Pseudothecosomatous pteropods use mucous webs manipulated by ciliary action to feed in the midwater (Gilmer, 1972), and larvaceans produce elaborate mucous feeding structures. Adult tubiculous chaetopterids feed by filtering through mucous bags manipulated by the aliform notopodia and cilia of the middorsal food groove (MacGinitie, 1939), and chaetopterid larvae are known to produce mucus (Nozais et al., 1997). It is likely that C. pugaporcinus feeds by the production of a mucous web that is manipulated by cilia of the middorsal groove and buccal area, although this was not observed directly.

Fecal pellets contained primarily skeletal remains of pelagic phytoplankton: coccolithophores, individual coccoliths, and diatom frustules (identified via scanning electron microscopy). They also contained pelagic foraminiferans, phaeodarians, silicoflagellates, dinoflagellates, as well as some unidentified soft material. Items in the fecal pellets were consistent with holopelagic suspension feeding on marine snow (KJO, unpubl. data).

Additionally, the mucous cloud may increase buoyancy, as also observed in Poecilochaetus larvae (Nozais et al., 1997). However, C. pugaporcinus specimens were able to maintain their positions in the aquaria for several hours without a mucous cloud.

\section{Behavior}

Chaetopterus pugaporcinus is neutrally buoyant, and when encountered in situ, each specimen was fully inflated, floating in the lower mesopelagic portion of the water column. The oral surface is relatively dense and keeps the animal's anterior end oriented down at all times. There was no active response to light, water disturbance, or the sound of the ROV, other than a slight contraction of regions A and
$\mathrm{C}$ and the middorsal ciliated groove. When physically disturbed in situ, specimens did not change their posture or the distended nature of region $\mathrm{B}$. When undisturbed in the laboratory, the animal floated in the upper one-third of the tank, attached to a mucous cloud. When exposed to isotonic magnesium chloride, or when the health of the animal deteriorated, the inflation of region $\mathrm{B}$ relaxed and the animal stretched longitudinally. No settling behavior was observed in animals kept in the laboratory, nor was swimming observed. There was no apparent ability to interact with any surface or object other than the mucous cloud. Specimens did not display any locomotory abilities.

One specimen was held in a still-water aquarium for $26 \mathrm{~h}$. The floor of the tank was furnished with deep-sea mud and sand more than three body lengths deep, with a cluster of rocks on one side. The specimen made no attempt to interact with the substrate during that period, nor was any sign of the onset of metamorphosis observed. Irvine et al. (1999) report that it takes as little as $6 \mathrm{~h}$ for an L5 stage Chaetopterus larva to reach late L7 stage and complete metamorphosis.

\section{Bioluminescence}

One specimen was examined for bioluminescence and was found to produce light in two forms. Only this single specimen was tested, due to the destructive nature of the physical stimulation. Bright blue light outlined the peristomium/prostomium after direct physical stimulation. The area glowed for 3-6 s, then abruptly extinguished. Additionally, minute green, bioluminescent particles were spewed from the middorsal ciliated groove or surrounding area, and the posterior end. These small glowing specks were dispersed throughout the mucous cloud produced at the same time, and glowed vividly for $1-2 \mathrm{~s}$ before fading slowly. The mucus and bioluminescent particles were apparently forced away from the body by as much as two body lengths.

Luminescence is common in Chaetopterus (Nicol, 1952; Martin and Anctil, 1984; Nishi, 2000). Transitory and undispersed light is produced when direct physical stimulation or freshwater are applied to the peristomial palps, feeding structures on the dorsal surface of region $\mathrm{B}$, and notopodia of region C. Nicol (1952) also found that photogenic glands on the aliform notopodia give off a luminescent secretion suspended in mucus that is dispersed in the surrounding water. Our observations do not conflict with any of these findings, but few comparisons can be drawn between them because of the differences in the structures present on $C$. pugaporcinus.

\section{Phylogenetic relationships}

Alignment of the concatenated sequences resulted in 3666 aligned base pairs. Of those, 2677 were either invariable or parsimony uninformative, leaving 989 parsimony 
informative base pairs. The equally weighted data matrix recovered two most parsimonious trees of length 5058, with a consistency index of 0.545 , a retention index of 0.449 , and a rescaled consistency index of 0.245 . The strict consensus of these trees is shown on the left side of Figure 5 with poorly supported nodes (having bootstrap and jackknife values below 70\%) collapsed.

Individual genes were also analyzed separately; informative sites included 513/1791 bp for the $18 S$ gene; 687/1151 for the $28 S$ gene, and 513/720 for the COI gene (162 first position, 112 second position, 239 third position). Individual gene trees are shown in Figure 6.

Chaetopteridae are consistently shown to be a monophyletic group containing two well-supported clades: clade 1 containing Mesochaetopterus and Chaetopterus and clade 2 containing Phyllochaetopterus and Spiochaetopterus (Figs. 5 and 6). Spiochaetopterus bergensis Gitay, 1969, is found nested among the Phyllochaetopterus terminals used here, suggesting that the latter may be paraphyletic, though further sampling of Spiochaetopterus is clearly needed.

Mesochaetopterus is found to be sister to Chaetopterus according to the $18 S$ sequence data (Fig. 6), as well as in the combined analysis (Fig. 5). However, the $28 S$ data show Mesochaetopterus nested among the Chaetopterus clade as sister group to $C$. pugaporcinus, and the COI data poorly supports the position of Mesochaetopterus in relation to Chaetopterus sp. 1.

Chaetopterus pugaporcinus falls as part of a Chaetopterus clade in the combined analysis, as well as with the $18 S$ and $C O I$ sequences alone. Thus this novel pelagic chaetopterid is designated here as a species of Chaetopterus despite its extreme morphological modifications.

The two specimens of $C$. pugaporcinus sequenced were found to have identical sequences for all genes, with the exception of one ambiguous base in the $28 \mathrm{~S}$ sequences. Total sequence differences between Chaetopterus specimens (total uncorrected divergence $=18 \mathrm{~S}: 0.4 \%$ to $1.6 \%$; 28S: $1.7 \%$ to $7.0 \%$; COI: $18 \%$ to $21 \%$ ) further support the idea that C. variopedatus sensu Hartman (1959) is actually a species complex and that the author unnecessarily synonymized a number of valid species. Chaetopterus pugaporcinus is considered a valid species owing to the sequence differences from Chaetopterus specimens collected from nearby localities for all three genes analyzed, as well as to their novel morphology.

\section{Discussion}

\section{Phylogenetic relationships}

All of our analyses place Chaetopterus pugaporcinus within clade 1 (Mesochaetopterus and Chaetopterus), suggesting that the novel species described here belongs to Chaetopterus. The combined data set shows that it is most reasonable to place the new species as part of Chaetopterus, as do the $18 S$ and COI data. The $28 S$ data would place both Mesochaetopterus and C. pugaporcinus within Chaetopterus. Thus we have conservatively named the new species as a Chaetopterus, coinciding with the morphological findings.

Relationships in and around the Chaetopteridae are not well known, yet the monophyly of the group has never been questioned owing to the uniqueness of the chaetopterid body form. All genes examined provided further strong support for the monophyly of the group.

Relationships within the Chaetopteridae have been proposed as far back as Potts (1914), and of the four genera, Chaetopterus and Mesochaetopterus are most similar to each other. They are distinguishable by a feature of the uncini (Bhaud et al., 2002), as well as by the number and arrangement of region $\mathrm{B}$ and $\mathrm{C}$ segments and parapodial form. Phyllochaetopterus and Spiochaetopterus are also similar to each other with respect to their modified chaetae and their uncini (Bhaud, 2003) and are separated by the presence (Phyllochaetopterus) or absence (Spiochaetopterus) of "tentacular cirri" on chaetiger 1 . Note that these tentacular cirri are in fact lobes containing chaetae (Rouse and Pleijel, 2001). Bhaud (2003) pointed out the difficulty of using hard parts (modified chaetae and uncini) to distinguish between Phyllochaetopterus and Spiochaetopterus, whereas these characters typically work well to distinguish these genera from Mesochaetopterus and Chaetopterus.

Our present data indicate that Mesochaetopterus is the sister group to Chaetopterus (Figs. 5 and 6), though this result is not apparent in the $28 S$ data. Great difficulties were encountered when amplifying DNA from Mesochaetopterus specimens (three $M$. taylori and one M. japonicus) for large subunit ribosomal $(28 S)$ and $C O I$ genes, suggesting that mutations have taken place in the primer regions used. This difficulty was not encountered consistently within any other taxa during this project, or with amplification of the $18 \mathrm{~S}$ ribosomal gene from Mesochaetopterus specimens. These mutations could be a synapomorphy for the group. Further taxon sampling, additional primer design/sequencing, and careful morphological work are necessary to fully determine the nature of the relationship between Mesochaetopterus and Chaetopterus.

\section{Suspended larvae or holopelagic paedomorphic species?}

There is no set number of days that chaetopterid larvae spend in the plankton; thus the larval period can be extended when appropriate habitat is not found (Bhaud et al., 1990; Hadfield and Strathmann, 1996). Whether the specimens described here are simply wayward larvae, swept off the continental shelf and unable to settle, thus growing to unusual size and developing adult features, or are the first known representatives of a holopelagic chaetopterid 


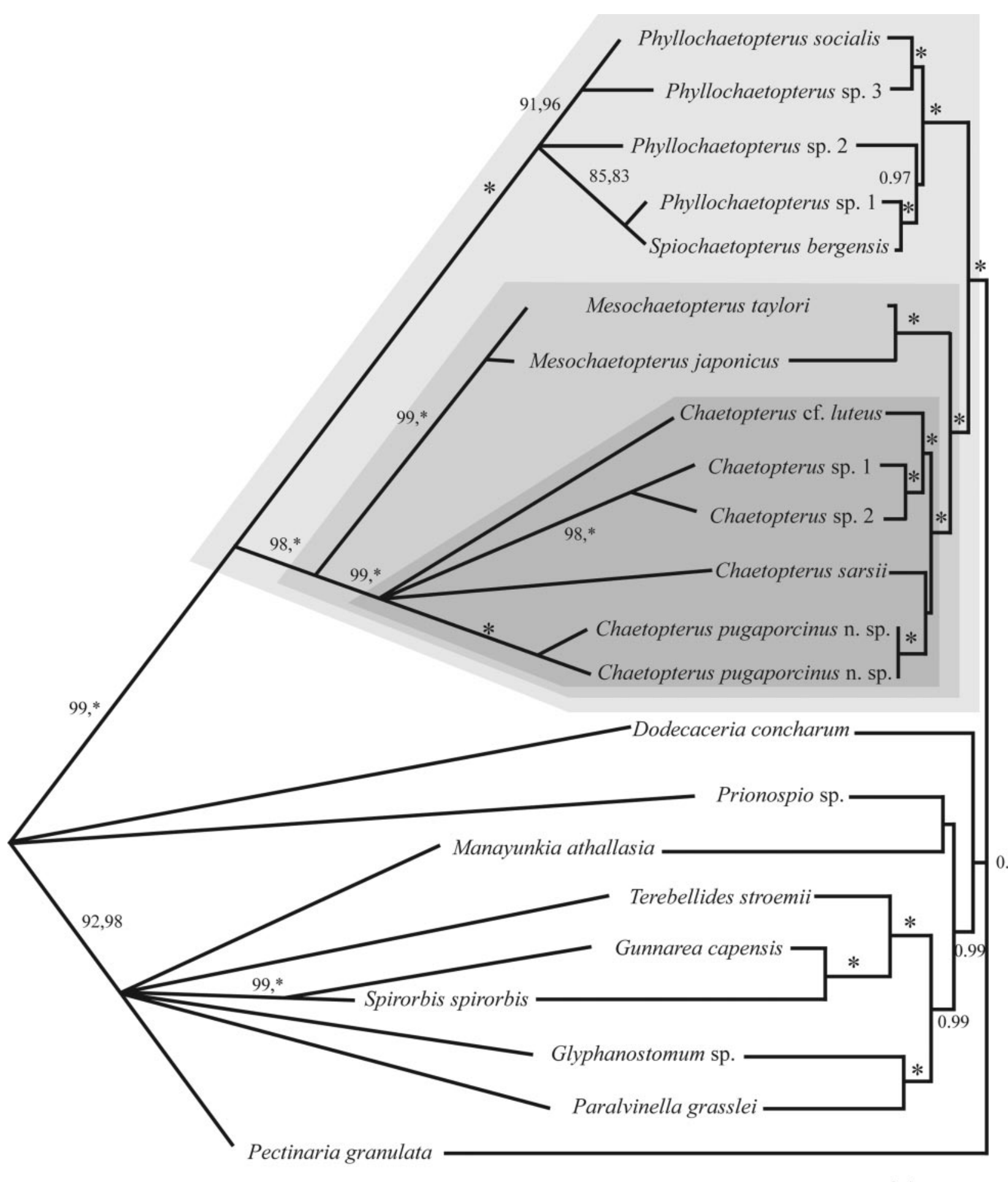

Figure 5. The strict consensus of the two most parsimonious trees from the parsimony analysis and the $70 \%$ majority rule Bayesian tree. Bootstrap and jackknife values (respectively) are given on the parsimony tree and posterior probabilities on the Bayesian tree. All values equal to $100 \%$ jackknife/bootstrap or 1.0 posterior probability are indicated with an asterisk. Branches not supported by at least $70 \%$ jackknife/bootstrap are collapsed on the parsimony tree, and posterior probabilities are provided only when greater than 0.95 . Chaetopteridae are highlighted in light gray, strict Chaetopterus in dark gray, and clade 1 in medium gray. 


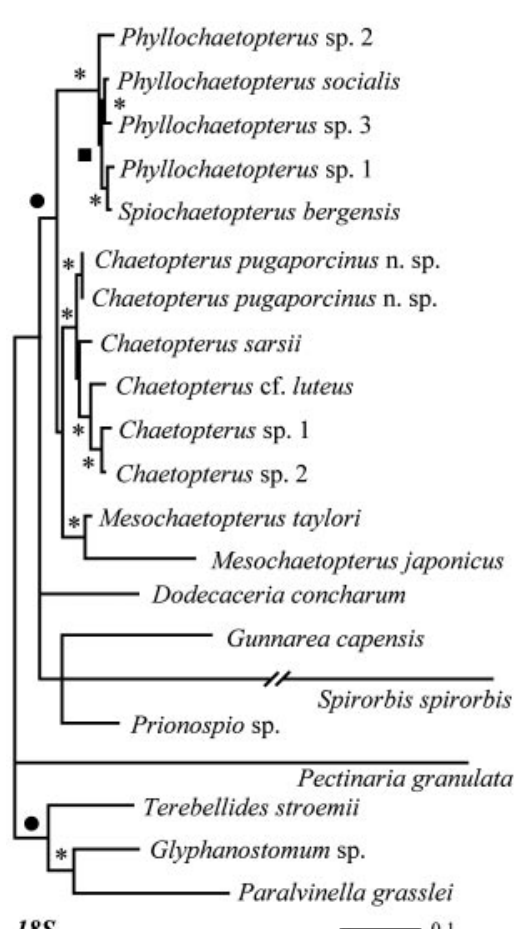

$18 S$

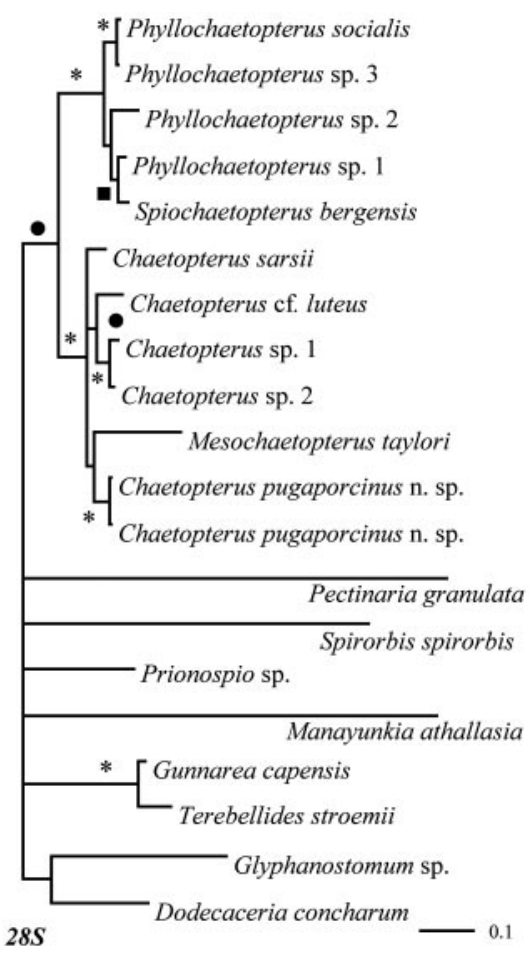

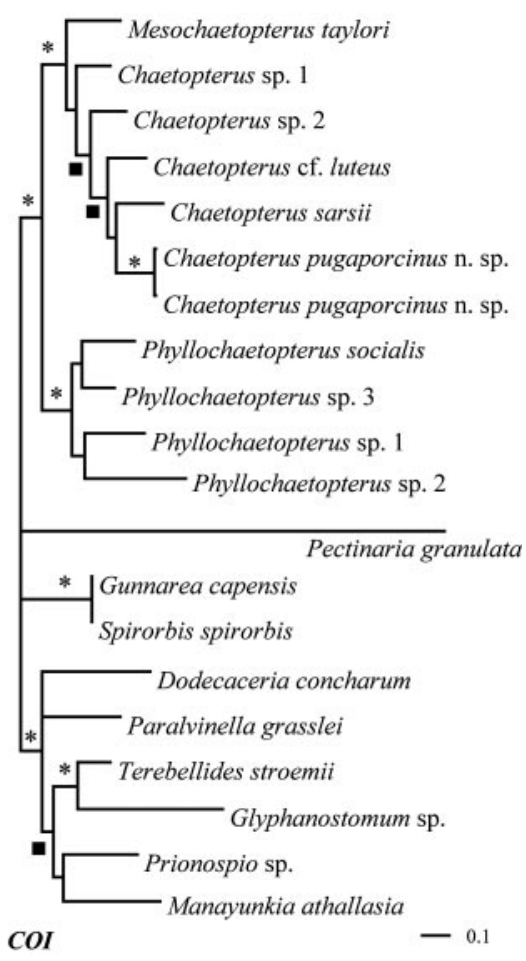

Figure 6. Individual gene trees generated from the 31 million generation Bayesian analyses of $18 \mathrm{~S}$, $28 \mathrm{~S}$, and COI sequences. Posterior probabilities equal to 1.0 are indicated with an asterisk, $0.98-0.99$ with a solid circle, and $0.90-0.97$ with a solid square near respective branches.

species, is yet to be resolved. However, we suggest that $C$. pugaporcinus is not a suspended larva waiting to metamorphose, despite the larval features present. Larval features of C. pugaporcinus include prostomial and peristomial form, lack of dorsoventral flattening of region A, lack of elongation of the body, form of pygidial tissue, and pelagic habitat. The principal evidence in favor of a holopelagic chaetopterid species is the lack of all ciliated mesotrochal rings and the presence of adult features. The latter include welldeveloped septation of segments A1-9, infolding of the epidermis designating segments of regions $\mathrm{B}$ and $\mathrm{C}$, presence of parapodia on segments of regions $\mathrm{B}$ and $\mathrm{C}$, and an enlarged coelomic cavity within region B. The same combination of larval, adult, and missing characters was found in each specimen, regardless of their broad size range $(10-21 \mathrm{~mm})$. If these were larvae waiting to settle, one would expect more adult features in the larger, older individuals and more larval features in the smaller, younger individuals, as found by Tzetlin (1998). However, the only differences we found were the relative lengths of the peristomial palps and possibly an additional region $\mathrm{C}$ segment in one medium-sized specimen. Palp length did not vary widely when considered relative to peristomium length, and palps are usually present in stage L5 Chaetopterus larvae. Palps no longer than the peristomium are a generic character of Chaetopterus.
Chaetopterus pugaporcinus was a particularly distinctive chaetopterid because, among other characters, it lacks modified A4 chaetae. If these specimens are larvae, they are nearly 10 times larger than any reported chaetopterid larva, and the largest is nearly twice the size of the largest larval polychaete reported (Tzetlin, 1998). A large larva would most likely metamorphose into a relatively large species, and it seems unlikely that such a distinctive macrofaunal species would have been unobserved with the extensive benthic sampling carried out off California (Blake, 1996), unless it is utilizing a poorly studied (midwater) or rare habitat. A large undescribed chaetopterid has indeed been found in large numbers around a whale fall in Monterey Bay (G.W. Rouse and C. E. Brady, unpubl. data), but it differs dramatically from C. pugaporcinus (Phyllochaetopterus sp. 1: tentacular cirri, uncini, glandular crescent, modified chaetae, and significant total uncorrected sequence divergence, 18S: $3 \%, 28 S: 13 \%$, COI: 26\%).

Chaetopterus pugaporcinus is found within a narrow depth range regardless of distance from shore or bottom depth, possibly suggesting adaptation to a specific habitat. In Monterey Bay, this depth range coincides with the bottom of the oxygen minimum zone. The lower interface of the oxygen minimum zone is often the site of concentrated marine snow and other debris that has fallen, essentially unchanged, through the above layer of low oxygen, and 
represents a relatively rich food source (Wishner et al., 1995). The ecological flexibility of chaetopterid larvae is well established (Bhaud and Duchène, 1996; Irvine et al., 1999), so it is reasonable to consider that a holopelagic form has arisen within the Chaetopteridae and that it resembles their pelagic larvae. Holopelagic polychaetes have evolved independently several times among annelids (Rouse and Pleijel, 2001).

Paedomorphosis (juvenile features retained in adults) is a mechanism of evolutionary change sometimes seen as simplification of the body, a feature common in mesopelagic animals (Herring, 2002) and may be the case with $C$. pugaporcinus. Chaetopterus pugaporcinus lacks the modified chaetae (cutting spines) used to cut the tube to allow for growth, a feature directly related to tubiculous living and one that may "weigh heavily" on a neutrally buoyant animal. It seems reasonable that these would be lost after adoption of a holopelagic lifestyle and therefore would be autapomorphic losses for $C$. pugaporcinus.

\section{Conclusions}

Chaetopterus pugaporcinus exhibits a combination of larval and adult features, and the habitat in which the specimens were found is typical only of chaetopterid larval stages. The question of adult status is not resolved because none of the eight specimens collected had recognizable reproductive products. This question would be fully resolved if a reproductive individual were collected in midwater or if a benthic adult were found that genetically and to some extent morphologically matched that described here. Regardless, the species introduced here is particularly interesting because of its great size and its continued survival deep in the water column with a consistent combination of larval and adult features. This prolonged survival is accomplished by retention of larval features already adapted to a pelagic life and loss of features necessary for a tubiculous life.

\section{Acknowledgments}

We are indebted to Fredrik Pleijel, Eijiroh Nishi, Robert Vrijenhoek, Shane Anderson, and Megan Dethier for providing specimens. Steve Haddock, Christy Schnitzler, W. Joseph Jones, C. Robert Young, and Lynne Christianson were extremely helpful with the molecular portion of the project. Jonathon Krupp and Kurt Buck were very helpful with the SEM work. Thanks also to the pilots of the ROVs Ventana and Tiburon, and the crews of the RVs Point Lobos and Western Flyer for their expertise and dedication to the exploration of the deep sea. Thanks to two reviewers for suggestions that improved the manuscript. A particular thanks is due Mary Petersen for advice and suggestions that greatly improved the manuscript. The David and Lucile
Packard Foundation provided support for this project through the MBARI Midwater Ecology Group.

\section{Literature Cited}

Akaike, H. 1974. New look at statistical model identification. IEEE Trans. Automatic Control 19: 716-723.

Bhaud, M. 1998. The spreading potential of polychaete larvae does not predict adult distributions: consequences for conditions of recruitment. Hydrobiologia 376: 35-47.

Bhaud, M., and C. Cazaux. 1987. Description and identification of polychaete larvae, their implications in current biological problems. Oceanis 13: 595-753.

Bhaud, M., and J. C. Duchène. 1996. Change from planktonic to benthic development: Is life cycle evolution an adaptive answer to the constraints of dispersal? Oceanol. Acta 19: 335-346.

Bhaud, M., and M. A. Fernandez-Alamo. 2000. Planktonic larvae of Spiochaetopterus in the Gulf of California: New evidence that the geographic distribution of species with a long planktonic larval life is relatively restricted (Polychaeta, Chaetopteridae). Ophelia 52: 65-76.

Bhaud, M., C. Cazaux, and M. H. Mathivat-Lallier. 1990. Métamorphose retardée chez les larves de polychètes et modèle d'acquisition de la vie benthique. Oceanis 16: 207-223.

Bhaud, M., M. C. Lastra, and M. E. Petersen. 1994. Redescription of Spiochaetopterus solitarius (Rioja, 1917), with notes on tube structure and comments on the generic status (Polychaeta: Chaetopteridae). Ophelia 40: 115-133.

Bhaud, M. R. 2003. Identification of adults and larvae in Spiochaetopterus (Polychaeta, Chaetopteridae): consequences for larval transport and recruitment. Hydrobiologia 496: 279-287.

Bhaud, M. R. and M. A. V. Petti. 2001. Spiochaetopterus nonatoi, a new species of Chaetopteridae (Polychaeta) from Brazil: biogeographical consequences. J. Mar. Biol. Assoc. UK 81: 225-234.

Bhaud, M. R., A. A. Ravara, G. Marcano, and M. H. Moreira. 2002. Mesochaetopterus sagittarius: an example of a biogeography discrepancy between larval and adult boundaries: implication for recruitment studies. J. Mar. Biol. Assoc. UK 82: 565-572.

Bhaud, M. R., D. Martin, and J. Gil. 2003. Spiochaetopterus creoceanae, a new species of Chaetopteridae (Polychaeta) from the Persian Gulf belonging to the costarum complex. Sci. Mar. 67: 99-105.

Blake, J. A. 1996. Family Chaetopteridae. Pp. 233-251 in Taxonomic Atlas of the Benthic Fauna of the Santa Maria Basin and Western Santa Barbara Channel, Vol. VI, J. A. Blake, B. Hilbig, and P. H. Scott, eds. Santa Barbara Museum of Natural History, Santa Barbara, CA.

Claparède, É. 1868. Les Annélides Chétopodes du Golfe de Naples. Mém. Soc. Phys. Hist. Nat. Genève 19: 313-584.

Crossland, C. 1904. The Polychaeta of the Maldive Archipelago from the collections made by J. Stanley Gardiner in 1899. Proc. Zool. Soc. Lond. 1: 270-286, pls 218-219.

Fauvel, P. 1927. Polychètes sédentaires. Addenda aux errantes, Arachiannélides, Myzostomaires. Faune Fr. 16: 1-494.

Folmer, O., M. Black, W. Hoeh, R. Lutz, and R. Vrijenhoek. 1994. DNA primers for amplification of mitochondiral cytochrome $\mathrm{C}$ oxidase subunit I from metazoan invertebrates. Mol. Mar. Biol. Biotechnol. 3: 294-299.

Gilmer, R. W. 1972. Free-floating mucus webs: a novel feeding adaptation for the open ocean. Science 176: 1239-1240.

Hadfield, M. G., and M. F. Strathmann. 1996. Variability, flexibility and plasticity in life histories of marine invertebrates. Oceanol. Acta 19: 323-334.

Hamner, W. H., L. P. Madin, A. L. Alldredge, R. W. Gilmer, and P. P. Hamner. 1975. Underwater observation of gelatinous zooplankton: sampling problems, feeding biology, and behavior. Limnol. Oceanogr. 20: $907-917$. 
Hartman, O. 1959. Catalogue of the polychaetous annelids of the world. Part II. Occasional Papers of the Allan Hancock Foundation 23: $1-353$.

Herring, P. 2002. The Biology of the Deep Ocean. Oxford University Press, Oxford.

Huelsenbeck, J. P., and F. Ronquist. 2001. MRBAYES: Bayesian inference of phylogenetic trees. Bioinformatics 17: 754-755.

Irvine, S. Q., O. Chaga, and M. Q. Martindale. 1999. Larval ontogenetic stages of Chaetopterus: developmental heterochrony in the evolution of chaetopterid polychaetes. Biol. Bull. 197: 319-331.

Lenaers, G., L. Maroteaux, B. Michot, and M. Herzog. 1989. Dinoflagellates in evolution: a molecular phylogenetic analysis of large subunit ribosomal RNA. J. Mol. Evol. 29: 40-51.

MacGinitie, G. E. 1939. The method of feeding of Chaetopterus. Biol. Bull. 77: 115-118.

Maddison, D. R., and W. P. Maddison. 2000. MacClade: Analysis of Phylogeny and Character Evolution. Sinauer Associates, Sunderland, MA.

Martin, N., and M. Anctil. 1984. Luminescence control in the tubeworm Chateopterus variopedatus: role of nerve cord and photogenic gland. Biol. Bull. 166: 583-593.

Medlin, L., H. J. Elwood, S. Stickel, and M. L. Sogin. 1988. The characterization of enzymatically amplified eukaryotic 16S-like rRNAcoding regions. Gene 71: 491-499.

Nicol, J. A. 1952. Studies on Chaetopterus variopedatus (Renier). I. The light-producing glands. J. Mar. Biol. Assoc. UK 30: 417-431.

Nishi, E. 2000. A new species of Chaetopterus (Polychaeta: Chaetopteridae) from off Tokyo Bay, Central Japan, with comments on its bioluminescence. Actinia (Bull. Manazura Mar. Lab. Yokohama Nat. Univ.) 13: 1-12.

Notredame, C., D. Higgins, and J. Heringa. 2000. T-Coffee: a novel method for multiple sequence alignments. J. Mol. Biol. 302: 205-217.

Nozais, C., J. C. Duchène, and M. R. Bhaud. 1997. Control of position in the water column by the larvae of Poecilochaetus serpens, (Polychaeta): the importance of mucus secretion. J. Exp. Mar. Biol. Ecol. 210: 91-106.

Pernet, B. 2004. The cryptic filtering house of an invertebrate larva. Science 306: 1757.

Petersen, M. E. 1984a. Chaetopterus variopedatus (Renier) (Annelida: Polychaeta: Chaetopteridae): a species complex. What species are being used at MBL? Biol. Bull. 167: 513 (abstract).

Petersen, M. E. 1984b. Chaetopterus variopedatus (Annelida: Polychaeta): another victim of the "characteristic species" disease. Am. Zool. 24: 62A (abstract).

Petersen, M. E. 1997. Contribution to a revision of Chaetopterus Cuvier (Polychaeta: Chaetopteridae): redescription of C. appendiculatus Grube and $C$. cautus Marenzeller, with comments on some other species. Bull. Mar. Sci. 60: 619-620 (abstract).

Petersen, M. E., and T. A. Britayev. 1997. A new genus and species of polynoid scaleworm commensal with Chaetopterus appendiculatus Grube from the Banda Sea (Annelida: Polychaeta), with a review of commensals of Chaetopteridae. Bull. Mar. Sci. 60: 261-276.

Posada, D., and K. A. Crandall. 1998. Modeltest: testing the model of DNA substitution. Bioinformatics 14: 917-918.

Posada, D., and K. A. Crandall. 2001. Selecting the best-fit model of nucleotide substitution. Syst. Biol. 50: 580-601.

Potts, F. A. 1914. Polychaeta from the N.E. Pacific: the Chaetopteridae. With an account of the phenomenon of asexual reproduction in Phyllochaetopterus and the description of two new species of Chaetopteridae from the Atlantic. Proc. Zool. Soc. Lond. 67: 955-994.

Rambaut, A., and A. J. Drummond. 2003. Tracer ver. 1.2. [Online] Available: http://evolve.zoo.ox.ac.uk/ [1 Oct. 2004].

Renier, S. A. 1804. Prospetto della Classe dei Vermi nominati e ordinati second oil sistema di Bosc. Zool. Jahrb. Syst., Jena 64: 41-110.

Robison, B. H. 1993. Midwater research methods with MBARI's ROV. Mar. Technol. Soc. J. 26: 32-39.

Rouse, G. W., and F. Pleijel. 2001. Polychaetes. Oxford University Press, Oxford.

Scheltema, R. S. 1974. Relationship of dispersal to geographical distribution and morphological variation in the polychaete family Chaetopteridae. Thalassia Jugosl. 10: 297-312.

Swofford, D. L. 2002. PAUP (Phylogenetic Analysis Using Parsimony). Sinauer Associates, Sunderland, MA.

Tzetlin, A. B. 1998. Giant pelagic larvae of Phyllodocidae (Polychaeta, Annelida). J. Morphol. 238: 93-107.

Uschakov, P. V. 1955. Polychaeta of the far eastern seas of the USSR Opredeliteli po Faune SSSR. 56: 1-445. Acad. Nauk SSSR (In Russian, translated by the Israel Program for Scientific Translations, 419 pp., 1965).

Wishner, K. F., C. J. Ashjian, C. Gelfman, M. M. Gowing, L. Kann, L. A. Levin, L. S. Mullineaux, and J. Salzman. 1995. Pelagic and benthic ecology of the lower interface of the Eastern Tropical Pacific Oxygen Minimum Zone. Deep-Sea Res. Part I Oceanogr. Res. Pap. 42: 93-115. 